\title{
KONSUMERISME DALAM PERSPEKTIF ISLAM
}

\author{
Eddy Rohayedi ${ }^{1}$, Maulina ${ }^{2}$ \\ Institut Agama Islam Negeri Palangka Raya ${ }^{1,2}$ \\ eddyrohayedi@gmail.com
}

\begin{abstract}
Most of the world community has become a modern society, modernization has a positive impact in facilitating daily activities, and it is closely related to consumer behavior (consumerism) which is embraced by the society consciously or unconsciously. This research describes how Islam views the consumerism. The method that used in this research is descriptive qualitative, which describes the phenomena that exist about consumerism in Islamic perspective. The type of qualitative research that used in this study is the study of documents or texts, which are studies of written documentary material in the form of textbooks, manuscripts, articles, and its kind. Data analysis procedure before in the field is to analyze result on the preliminary observational study. The analysis during the field uses Miles and Huberman's model analysis, which suggests that the activities and analysis of qualitative data are carried out interactively and continuously until completion, thus the data is already saturated. Data analysis consist data collection, data reduction, data presentation, and analysis/conclusion. The results shows that consumerism is excessive and irrational consumption behavior that prioritizes desires rather than needs by not prioritizing benefits that tend to be wasteful, satisfaction, and self-recognition. For Islamic perspective, consumerism is forbidden because it belongs to excessive behavior, is only oriented to worldly satisfaction and arrogance. Islam teaches consumption behavior that embraces the understanding of balance in various aspects, according to needs and has a value of benefits in accordance with rationality, which means that if properly understood the concept of consumption taught by Islam then humans can limit their desires in accordance with the needs and benefits that lead to the reduced behavior wasteful, miserly, and arrogant behavior.
\end{abstract}

Keywords: Islam, consumerism

Sejak lahir manusia sudah melakukan praktik konsumsi, sebagai contoh bayi lahir memakai pakaian dan perlengkapan lainnya agar dapat tumbuh berkembang dengan baik. Dalam kehidupannya manusia tidak lepas dari aktivitas konsumsi, sederhananya manusia perlu sandang, pangan dan papan untuk bertahan di kehidupan ini. Menurut Kamus Besar Bahasa Indonesia (KBBI Online, 2020) konsumsi adalah pemakaian barang hasil produksi (bahan makanan, pakaian dan sebagainya), barang-barang yang langsung memenuhi keperluan hidup. 
Seiring dengan perkembangan kehidupan manusia, perubahan-perubahan terus terjadi, modernisasi merupakan salah satu bentuk perubahan yang terjadi pada manusia. Pada masa sekarang hampir seluruh negara terpengaruh modernisasi, terlihat dari perilaku masyarakat yang terus mengalami perubahan dan keluar dari sikap-sikap ketradisionalannya, seperti: penggunaan sepeda motor dan mobil dalam melakukan perjalanan, memasak dengan peralatan bermesin, penggunaan teknologi informasi dalam melakukan segala macam aktivitas dan lain sebagainya. Modernisasi erat kaitannya dengan perilaku konsumtif yang dianut masyarakat secara sadar maupun tidak disadari. Modernisasi memiliki dampak positif salah satunya mempermudah manusia dalam menjalankan aktifitas sehari-hari, namun juga pada saat ini kebutuhan manusia tidak hanya sekedar dalam mempermudah dirinya dalam menjalankan kehidupan sehari-hari akan tetapi keinginan untuk terlihat "modern" dengan menerapkan perilaku konsumtif melebihi batas kebutuhan bahkan penghasilannya seperti sudah menjadi tren, keinginan untuk terlihat menonjol dan istimewa marak terlihat.

Fauzia dan Riyaldi (2014:180) mengatakan semua lapisan masyarakat tanpa mengenal usia dan strata sosial sudah terbawa oleh derasnya arus konsumerisme. Menurut Setiaji dalam Fauzia dan Riyaldi (2014:182) perubahan budaya menurut budaya konsumerisme terjadi hampir di seluruh belahan dunia, di Inggris hal itu telah mulai terjadi pada abad VXIII. Hal yang sama juga kemudian muncul di Amerika, Prancis dan di tempat-tempat lain sejalan dengan dikembangkannya budaya berorientasi konsumsi seperti di negara-negara Asia, Amerika Selatan, Afrika dan Eropa Timur. Masyarakat modern dapat dikatakan sebagai masyarakat konsumtif, konsumsi yang dilakukan bukan lagi sekedar kegiatan pemenuhan kebutuhan-kebutuhan dasar dan fungsional manusia. Masyarakat modern tidak cukup hanya mengkonsumsi sandang, pangan, dan papan saja untuk dapat bertahan hidup. Meskipun secara biologis kebutuhan makanan dan pakaian telah cukup terpenuhi, namun untuk kebutuhan dalam tatanan pergaulan sosial dengan sesama manusia lainnya, manusia modern harus mengkonsumsi lebih dari itu. Dapat dikatakan bahwa masyarakat modern saat ini hidup dalam budaya konsumen. Sebagai suatu budaya, konsumsi sangat 
mempengaruhi kehidupan sehari-hari dan mampu menstruktur kegiatan keseharian di masyarakat. Nilai-nilai pemaknaan dan harga diri menjadikan sesuatu yang dikonsumsi menjadi semakin penting dalam pengalaman personal dan kehidupan sosial masyarakat. Konsumsi telah masuk ke dalam rasionalitas berpikir masyarakat dan teraplikasikan dalam kehidupan sehari-hari. Beberapa penelitian yang berkaitan dengan perilaku konsumtif adalah penelitian Jamil, Arsyad dan Upe (2018) di antaranya menyebutkan bahwa bentuk perilaku konsumer pengunjung mall yaitu hidup mewah, mentalitas instan dan boros, yang menjadi motivasi adalah dari segi refresing dan meningkatkan status sosial; penelitian Tripambudi dan Indrawati (2018) mengungkapkan hasil dari penelitiannya mengenai perilaku konsumsi, bahwa semakin tinggi kontrol diri maka semakin rendah perilaku pembelian gadget, semakin rendah kontrol diri maka semakin tinggi perilaku pembelian gadget. Dari pendapat para ahli tersebut dapat diartikan, bahwa konsumerisme adalah budaya konsumsi atas dasar keinginan, kepuasan dan harga diri, lebih dari sekedar kebutuhan bahkan bukan kebutuhan.

Dalam Islam, segala yang dilakukan oleh umat manusia diatur dan dimanfaatkan atas dasar kesejahteraan, bukan berlebih-lebihan walaupun memiliki pendapatan yang banyak. Berkaitan dengan budaya konsumerisme, bahwa Islam sangat tidak mengajurkan, sebagaimana diatur dalam Al Qur'an Surah Al A'raaf ayat 31, yang artinya "Hai anak Adam, pakailah pakaianmu yang indah di setiap (memasuki) masjid, makan dan minumlah, dan janganlah berlebih-lebihan. Sesungguhnya Allah tidak menyukai orang-orang yang berlebih-lebihan”. Dalam Hadis Riwayat Imam Ahmad Matan lain: An-Nasa'i (2512), Ibnu Majah (3595), al-Hakim dan dihasankan dalam Sahih al-Jami' ash Shagir (4505) Nabi Muhammad SAW bersabda "makan dan minumlah, bersedekahlah serta berpakaianlah dengan tidak berlebih-lebihan”. Ayat Al Qur'an dan hadis tersebut menunjukkan bahwa Islam mengajarkan perilaku konsumsi yang tidak berlebihan, yang berarti bahwa jika memahami betul konsep konsumsi yang diajarkan oleh Islam maka manusia dapat membatasi nafsu keinginannya sesuai dengan kebutuhan saja. 
Tulisan ini berupaya mendeskripsikan mengenai bagaimana konsumerisme dalam perspektif Islam berdasarkan fakta-fakta, pendapat-pendapat ahli dan Kalam Ilahi yang mengatur perilaku konsumsi manusia.

\section{METODE}

Pendekatan yang digunakan oleh peneliti adalah penelitian deskriptif, menurut Sukmadinata (2011:64) penelitian deskriptif adalah suatu metode penelitian yang ditujukan untuk menggambarkan fenomena-fenomena yang ada, yang berlangsung pada saat ini atau saat lampau. Penelitian ini bersifat kualitatif, menurut Strauss dan Corbin (1997) dalam Sujarweni (2014:19) yang dimaksud penelitian kualitatif adalah jenis penelitian yang menghasilkan penemuanpenemuan yang tidak dapat dicapai (diperoleh) dengan menggunakan prosedurprosedur statistik atau cara lain dari kuantifikasi (pengukuran). Penelitian kualitatif secara umum dapat digunakan untuk penelitian tentang kehidupan masyarakat, sejarah, tingkah laku, fungsionalisasi organisasi, aktivitas social dan lain-lain.

Jenis penelitian kualitatif yang digunakan dalam penelitian ini adalah studi dokumen atau teks, yang merupakan kajian dari bahan dokumenter tertulis berupa buku teks, surat kabar online, naskah, artikel dan sejenisnya. Prosesnya adalah dokumen atau teks tersebut dianalisis, diinterpretasikan, digali untuk menentukan pencapaian pemahaman terhadap topik tertentu dari bahan tersebut, yang kemudian dikaitkan dan dituangkan dalam penelitian ini.

Prosedur pengumpulan data dilakukan dalam tahap-tahap berikut:

1. Dilakukan orientasi dimana peneliti perlu mengumpulkan data secara umum dan luas tentang hal-hal yang menonjol, menarik dan berguna untuk diteliti lebih mendalam dari topik penelitian, yaitu konsumerisme dalam perspektif Islam.

2. Mengadakan eksplorasi pengumpulan data yang dilakukan lebih terarah sesuai dengan fokus penelitian serta mengetahui sumber data yang kompeten dan mempunyai pengetahuan yang cukup banyak tentang hal yang akan diteliti. 
3. Peneliti melakukan penelitian pada masalah pokok penelitian, yakni Konsumerisme dalam perspektif Islam

Prosedur analisis data dilakukan dalam tahap-tahap berikut:

1. Analisis sebelum di lapangan

Peneliti menggunakan analisis data sebelum peneliti memasuki lapangan dilakukan terhadap data hasil studi pendahuluan observasi awal yaitu mencari litelatur mengenai konsumsi dalam Islam dan melihat gejala-gejala yang sedang tren saat ini yaitu perilaku konsumtif dari sebagian besar masyarakat, dan dikaitkan dengan pola konsumsi dalam Islam yang digunakan untuk menentukan fokus penelitian.

2. Analisis selama di lapangan Model Miles dan Huberman

Selama di lapangan peneliti menggunakan analisis model Miles dan Huberman. Miles dan Huberman (1994) dalam Darwis (2014:57) mengemukakan bahwa aktivitas dan analisis data kualitatif mengenai konsumerisme dalam perspektif Islam dilakukan secara interaktif dan berlangsung secara terus menerus sampai tuntas, sehingga datanya sudah jenuh. Aktivitas dalam analisis data, yaitu pengumpulan data, reduksi data, sajian data dan analisis/kesimpulan. Langkahlangkah analisis data Miles dan Huberman ditunjukan pada gambar berikut:

Gambar 1. Analisis Komponen Model Miles dan Huberman

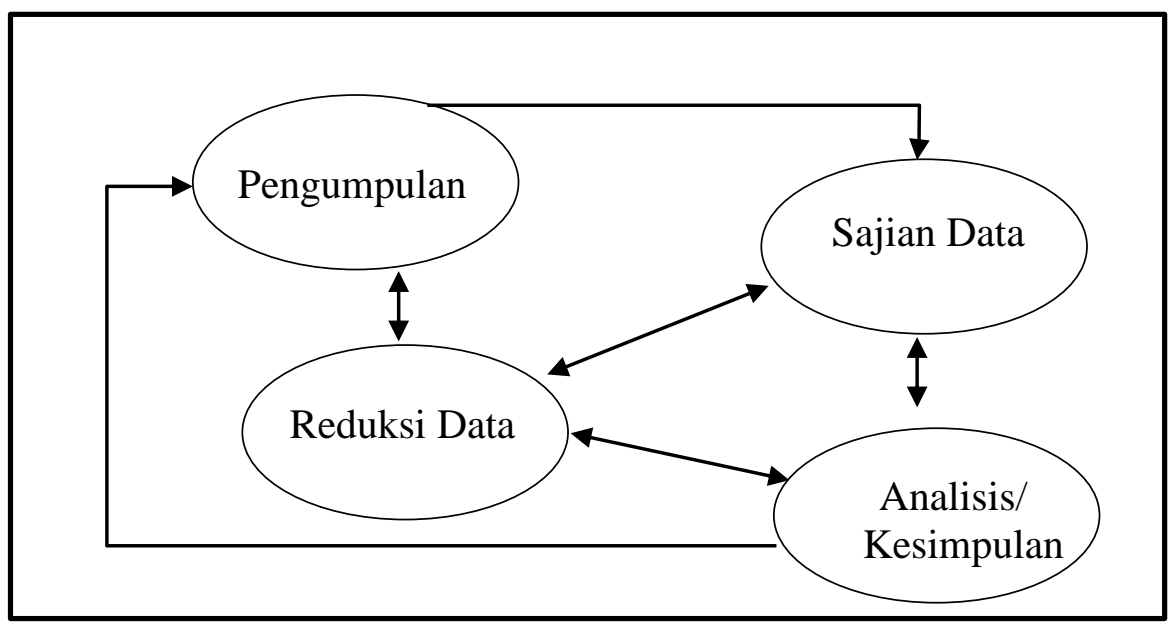




\section{HASIL DAN PEMBAHASAN}

\section{Deskripsi Perilaku Konsumtif (Konsumerisme)}

Perilaku konsumtif atau konsumerisme menurut Setiaji (1995) adalah kecenderungan seseorang berperilaku berlebihan dalam membeli sesuatu atau membeli secara tidak terencana. Sebagai akibatnya mereka kemudian membelanjakan uangnya dengan membabi buta dan tidak rasional, sekedar untuk mendapatkan barang-barang yang menurut anggapan mereka dapat menjadi simbol keistimewaan. Triyaningsih (2011) berpendapat perilaku konsumtif merupakan perilaku membeli dan menggunakan barang yang tidak didasarkan atas pertimbangan secara rasional dan memiliki kecenderungan untuk mengkonsumsi sesuatu tanpa batas dimana individu lebih mementingkan faktor keinginan daripada kebutuhan serta ditandai oleh adanya kebutuhan mewah dan berlebihan, penggunaan segala hal yang paling mewah memberikan kepuasan dan kenyamanan fisik. Sependapat dengan pengertian tersebut, Rosandi dalam Yuniarti (2015:26) mengatakan perilaku konsumtif adalah suatu perilaku membeli yang tidak didasarkan pada pertimbangan yang rasional, karena adanya keinginan yang sudah mencapai taraf yang tidak rasional lagi.

Dari pendapat para ahli tersebut, terdapat dua sifat yang mendominasi pada paham konsumerisme yaitu berlebihan, tidak rasional, berorientasi pada kepuasan dan pengakuan diri. Dalam konsumerisme, perilaku konsumen mudah terbujuk oleh promosi dari suatu produk tanpa mengedepankan aspek kebutuhan atau kepentingan, lebih memilih barang-barang bermerek yang sudah dikenal luas tanpa melihat keterjaminan mutu produk itu sendiri, dan memilih barang tidak berdasarkan kebutuhan melainkan keinginan dan gengsi.

\section{Faktor Pendorong Perilaku Konsumtif (Konsumerisme)}

Menurut Sutisna dalam Fauzia dan Riyadi (2014:185) seorang konsumen tertarik untuk melakukan transaksi pembelian dikarenakan faktor budaya, sosial, personal dan psikologi. Juga di dalam membuat keputusan untuk membeli suatu produk ataupun jasa, ada beberapa hal yang memengaruhi dan mendorong 
seseorang untuk melakukan pembelian. Salah satunya suatu pemasaran yang agresif dan juga adanya iklan-iklan yang persuasif.

Kurniawan (2017) dalam penelitiannya, mengatakan faktor-faktor yang mempengaruhi perilaku konsumtif:

1. Pembeli ingin tampak berbeda dari yang lain, kebanyakan sifat konsumtif muncul karena pembeli ingin memiliki barang yang tidak dipunyai orang lain, Alhasil pembeli pun akan mencari barang yang langka atau limited edition tentu saja harganya pun juga pastinya sangat mahal.

2. Kebanggaan karena penampilan dirinya, sifat konsumtif juga biasa terjadi karena rasa kebanggaan yang berlebih terhadap penampilan. Biasanya banyak diantaranya ada orang akan percaya diri bila memiliki barang-barang mewah dan selalu update/terbaru.

3. Ikut-ikutan, ada juga sifat orang yang ikut-ikutan dengan orang lain sehingga apapun itu akan selalu dibeli dan ingin selalu memiliki barang-barang yang sedang terkenal seiring perkembanagan zaman.

4. Menarik perhatian dari orang lain, adalah salah satu yang paling berpengaruh terhadap perilaku konsumtif seseorang, biasanya orang yang selalu ingin menarik perhatian orang lain pasti memiliki cara, salah satunya yaitu memiliki barang-barang yang up-to-date. Kecenderungan orang-orang akan memaksimalkan kegiatan belanja mereka bukan lagi sesuai kebutuhan primer sehari-hari akan tetapi sesuai selera mereka masing-masing (tersier).

Menurut Triyaningsih (2011), faktor-faktor yang mempengaruhi perilaku konsumtif adalah sebagai berikut:

1. Hadirnya iklan merupakan pesan yang menawarkan suatu produk yang ditujukan pada khalayak melalui media massa yang bertujuan untuk mempengaruhi masyarakat untuk mencoba dan akhirnya membeli produk yang ditawarkan.

2. Konformitas terjadi disebabkan karena keinginan yang kuat pada individu untuk tampil menarik dan tidak berbeda dari kelompoknya serta dapat diterima sebagai bagian dari kelompoknya. 
3. Gaya hidup merupakan salah satu faktor utama yang munculnya perilaku konsumtif. Gaya hidup yang dimaksud adalah gaya hidup yang meniru orang luar negeri yang memakai produk mewah dari luar negeri yang dianggap meningkatkan status sosial seseorang.

4. Kartu kredit digunakan oleh pengguna tanpa takut tidak mempunyai uang untuk berbelanja.

Dari pendapat-pendapat mengenai faktor-faktor pendorong perilaku konsumtif, dapat dianalisa bahwa kebanyakan faktor-faktor yang mendominasi adalah faktor internal, yaitu keinginan dan pengakuan diri. Faktor eksternal seperti iklan sebagai ajang promosi barang dan jasa adalah pemancing, tergantung kepada pemikiran masing-masing individu.

\section{Konsumerisme dalam Perspektif Islam}

Salah satu perbedaan mendasar antara sistem ekonomi Islam dan konvensional adalah menyoroti masalah kebutuhan dan keinginan. Kebutuhan biasanya terkait dengan sesuatu yang harus dipenuhi, segala keperluan dasar manusia untuk kehidupannya. Khan dalam Rozalinda (2016:105) mengatakan dalam perspektif ekonomi Islam, semua barang dan jasa membawa pengaruh pada kemaslahatan disebut dengan kebutuhan manusia. Misal makan makanan yang halal dan bergizi merupakan kebutuhan manusia agar tetap hidup sehat. Keinginan adalah sesuatu yang terkait dengan hasrat, jika dipenuhi belum tentu meningkatkan kesempurnaan fungsi manusia ataupun sesuatu. Keinginan merupakan bentuk kebutuhan manusia yang dihasilkan oleh budaya dan kepribadian individual, manusia mempunyai keinginan nyaris tanpa batas, tetapi sumber dayanya terbatas.

Rozalinda (2016:107) mengatakan dalam ekonomi konvensional tidak dibedakan antara kebutuhan dan keinginan, konsep kapitalis sangat mengedepankan keinginan. Keinginan dapat dijadikan standar kepuasan bagaimana manusia mencukupi kebutuhan hidupnya. Konsep inilah yang menjebak manusia dalam perilaku konsumtif atau konsumerisme. Berbeda dengan konvensional, Islam mengenal adanya keseimbangan. Konsep keperluan dasar 
manusia adalah dinamis merujuk pada tingkat ekonomi yang ada pada masyarakat. Dapat saja pada tingkat ekonomi tertentu sebuah barang dikonsumsi karena motivasi keinginan, pada tingkat ekonomi yang lebih baik barang tersebut menjadi sebuah kebutuhan, misalnya laptop, pada tingkat ekonomi tertentu ia dikonsumsi karena keinginan, akan tetapi pada kondisi dalam melaksanakan pekerjaan atau pendidikan tertentu laptop menjadi sebuah kebutuhan. Al Ghazali seorang pemikir Islam dalam Janwari (2016:189) mengingatkan untuk tidak berlebihan dalam memenuhi kebutuhan duniawi.

Menurut Arif (2017:206) Islam tidak melarang manusia untuk memenuhi kebutuhan ataupun keinginannya, selama dengan pemenuhan tersebut martabat manusia bisa meningkat dan manusia diperintahkan untuk mengkonsumsi barang dan jasa yang halal dan baik secara wajar serta tidak berlebihan. Pemenuhan kebutuhan ataupun keinginan dibolehkan selama hal itu mampu menambah maslahah dan tidak mendatangkan kemudaratan.

Menurut Arif (2017:188), konsumsi berlebih-lebihan merupakan ciri khas masyarakat yang tidak mengenal Tuhan, dikutuk dalam Islam dan disebut dengan israf (pemborosan) atau tadzir (menghambur-hamburkan harta tanpa guna). Ajaran-ajaran Islam menganjurkan pola konsumsi dan penggunaan harta secara wajar dan berimbang, yaitu pola yang terletak diantara kekikiran dan pemborosan, Janwari (2016:31) menyatakan hal yang sama dengan sebutan prinsip pertengahan, umat Islam ditetapkan untuk menghabiskan dan mngonsumsi barang dalam pertengahan. Pada satu sisi manusia bersikap dermawan, tetapi pada saat yang bersamaan mereka juga tidak boleh berlebihan, baik untuk dirinya sendiri, keluarga maupun tanggungan mereka. Prinsip pertengahan berlaku untuk belanja konsumsi barang dan konsumsi jasa pada berbagai tingkat kebutuhan. Para fuqaha telah membagi tingkat konsumsi menjadi tiga tingkatan utama yaitu, primer (dharuriyat), sekunder (hajiyat) dan tersier (tahsiniyat). Pemenuhan konsumsi primer dimaksudkan untuk mewujudkan kelangsungan hidup meliputi makanan, tempat tinggal, agama, pakaiandan pernikahan. Pemenuhan konsumsi sekunder untuk mempertahankan prinsip-prinsip dasar kehidupan, mencakup barang dan jasa yang masih dihitung sebagai kebutuhan dasar meskipun tidak dalam hal jenis, 
jumlah dan kualitas yang sangat dibutuhkan seperti pada kebutuhan primer. Pemenuhan konsumsi tersier dimaksudkan untuk mewujudkan kehidupan lebih nyaman dan menyenangkan, termasuk di dalamnya adalah barang mewah. Seluruh tingkat kebutuhan tersebut harus diwujudkan oleh konsumen muslim dengan memperhatikan prinsip pertengahan.

Salah satu ciri penting dalam Islam adalah bahwa ia tidak hanya mengubah nilai-nilai dan kebiasaan-kebiasaan masyarakat, tetapi juga menyajikan kerangka legislatif yang perlu untuk mendukung dan memperkuat tujuan-tujuan dan menghindari penyalahgunaan. Ciri khas Islam juga memiliki daya aplikatif terhadap orang yang terlinbat dalam pemborosan. Dalam hukum Islam, orang semacam itu seharusnya dikenai pembatasan-pembatasan dan jika dianggap perlu dilepaskan dan dibebaskan dari tugas mengurus harta miliknya sendiri. Dalam pandangan syariat ia seharusnya diperlakukan sebagai orang yang tidak mampu dan orang lain seharusnya yang mengurus hartanya selaku wakilnya. (Arif, 2017:189). Jika syariat Islam ini diterapkan, konsumerisme tidak akan ada.

Janwari (2016:30) berpendapat Islam sebagai agama yang lengkap tidak mengakui pemisahan antara masalah agama, politik dan ekonomi. Bagi umat Islam, Islam menyediakan cara hidup yang komprehensif. Oleh karena itu masalah ekonomi Islam harus dilihat dalam konteks nilai-nilai etika. Hal ini sangat esensial mengingat agama itu datang dalam rangka meningkatkan sistem kehidupan secara menyeluruh, mendorong perkembangan spiritual individu dan memperbaiki ketidak seimbangan sosial ekonomi dalam masyarakat dengan bergerak kearah keadilan sosial. Penggunaan konsep ini akan mengharuskan konsumen dalam masyarakat Islam diharapkan untuk bertindak sesuai dengan nilai-nilai etika Islam.

Rozalinda (2016:108) mengatakan nilai-nilai etika Islam yang harus diaplikasikan dalam konsumsi adalah:

1. Seimbang dalam konsumsi.

Islam mewajibkan kepada pemilik harta agar menafkahkan sebagian hartanya untuk diri sendiri, keluarga dan fi sabilillah. Islam mengharamkan sifat kikir, boros dan menghamburkan harta. Inilah bentuk keseimbangan yang 
diperintahkan dalam Al Qur'an, seperti diisyaratkan dalam Q.S. Al Isra ayat 29 “dan janganlah kamu jadikan tanganmu terbelenggu pada pundakmu dan janganlah kamu terlalu mengulurkannya karena itu akan menjadikanmu tercela dan menyesal” dan Q.S. Al Isra Ayat 26-27 “dan janganlah kamu menghamburhamburkan hartamu secara boros, sesungguhnya pemboros-pemboros itu adalah saudara-saudara setan dan setan itu adalah sangat ingkar kepada Tuhannya" Menurut Al Ghazali dalam Janwari (2016:191) perilaku Islam yang benar adalah selalu berbagi kekayaan secara sukarela sebagai bagian dari ajaran syariah, yang berarti melarang untuk memiliki sifat kikir, dia juga menyatakan bahwa harta telah diciptakan untuk sebuah tujuan, yaitu untuk memenuhi kebutuhan manusia yang harus digunakan secara adil dan optimal, sifat yang dikehendaki syariah adalah tidak terlalu boros dan tidak terlalu kikir yaitu mengeluarkan harta saat dibutuhkan dan menahan diri saat tidak dibutuhkan.

2. Membelanjakan harta pada bentuk yang dihalalkan dan dengan cara yang baik

Islam mendorong dan memberi kebebasan kepada manusia agar membelanjakan hartanya untuk membeli barang-barang yang baik dan halal, kebebasan tersebut dengan ketentuan tidak melanggar batas suci serta tidak mendatangkan bahaya seperti judi yang hanya memperturutkan hawa nafsu.

\section{Larangan bersikap Israf (royal) dan Tadzir (sia-sia)}

Adapun nilai-nilai akhlak yang terdapat dalam konsep konsumsi adalah pelarangan terhadap sikap hidup mewah. Sependapat dengan pernyataan ini, Pradja (2015:69) dalam ekonomi Islam hidup sederhana itu suatu nilai bertolak belakang dengan ekonomi kapitalis yang menganggap konsumerisme adalah suatu nilai. Konsumerisme identik dengan gaya hidup mewah. Gaya hidup mewah sebagai perusak individu dan masyarakat, karena menyibukkan manusia dengan hawa nafsu, melalaikan dari hal hal mulia dan akhlak yang luhur. Ali Abd ArRasul dalam Rozalinda (2016:109) menilai dalam masalah ini bahwa gaya hidup mewah merupakan faktor yang memicu terjadinya dekadensi moral masyarakat yang akhirnya membawa kehancuran masyarakat tersebut. Bagi Afzalur Rahman 
dalam Rozalinda (2016:109) kemewahan merupakan berlebih-lebihan dalam kepuasan pribadi dan membelanjakan harta untuk hal-hal yang tidak perlu. Dalam Q.S. Al A'raaf ayat 31, Allah berfirman "hai anak Adam, pakailah pakaian yang indah di setiap (memasuki masjid), makan dan minumlah kamu dan janganlah berlebih-lebihan. Sesungguhnya Allah tidak menyukai orang-orang yang berlebih-lebihan.

Sikap mewah biasanya diiringi hidup berlebih-lebihan (melampaui batas atau israf). Israf atau royal menurut Alfazul Rahman dalam Rozalinda (2016:219) ada tiga pengertian, yaitu menghambur-hamburkan kekayaan pada hal-hal yang diharamkan seperti mabuk-mabukan dan berjudi; pengeluaran yang berlebihlebihan pada hal-hal yang dihalalkan tanpa perduli apakah sesuai dengan kemampuan atau tidak, dan pengeluaran dengan alasan kedemawanan hanya sekedar pamer belaka. Islam memuji dan menyanjung sikap orang-orang yang berbuat ekonomis dan hemat dalam kehidupan mereka. Dalam hal ini, Islam menginginkan sikap ekonomis menjadi moral agama yang fundamental dan moral pribadi kaum Muslim.

Menurut Naqvi dalam Arif (2017:189-193) etika Islam dalam konsumsi adalah sebagai berikut:

1. Tauhid (Unity/kesatuan)

Dalam perspektif Islam, kegiatan konsumsi dilakukan dalam rangka beribadah kepada Allah SWT. Oleh karena itu, orang mukmin berusaha mencari kenikmatan dengan menaati perintah-perintah-Nya dan memuaskan dirinya sendiri dengan barang-barang dan anugrah-anugrah yang diciptakan-Nya untuk umat manusia. Adapun dalam pandangan kapilatis, konsumsi merupakan fungsi dari keinginan, nafsu, harga barang, pendapatan dan lain-lain tanpa memedulikan dimensi spiritual, kepentingan orang lain dan tanggung jawab atas segala perilakunya sehingga pada ekonomi konvensional, manusia dapat diartikan sebagai individu yang memiliki sifat homo economicus. Dalam Islam posisi manusia dijelaskan pada firman Allah SWT dalam Q.S. Az Zariyat ayat 56: "Aku tidak menciptakan jin dan manusia melainkan agar mereka beribadah kepada-Ku". 


\section{Adil}

Islam memperbolehkan manusia untuk menikmati karunia kehidupan dunia yang disediakan Allah SWT. Akan tetapi, pemanfaatan atas karunia Allah SWT tersebut harus dilakukan secara adil sesuai dengan syariat sehingga selain mendapatkan keuntungan material, ia juga merasakan kepuasan spiritual. Al Qur'an secara tegas menekankan norma perilaku ini, baik untuk hal-hal yang bersifat material maupun spiritual untuk menjamin adanya kehidupan yang berimbang antara kehidupan dunia dan kehidupan akhirat. Oleh karena itu, dalam Islam konsumsi tidak hanya barang-barang yang bersifat duniawi, tetapi juga untuk kepentingan di jalan Allah SWT. Allah berfirman dalam Q.S. Al Isra ayat 16: "Dan jika kami hendak membinasakan suatu negeri, maka kami perintahkan kepada orang yang hidup mewah di negeri itu (agar menaati Allah), tetapi bila mereka melakukan kedurhakaan di dalam (negeri) itu, maka sepantasnya berlakulah terhadapnya perkataan (hukuman Kami), kemudian Kami binasakan sama sekali (negeri itu)."

\section{Kehendak Bebas}

Alam semesta adalah milik Allah SWT, yang memiliki kemahakuasaan (kedaulatan) sepenuhnya dan kesempurnaan atas makhluk-makhluk-Nya. Manusia diberi kekuasaan untuk mengambil keuntungan dan manfaat sebanyak-banyaknya sesuai dengan kemampuannya atas barang-barang ciptaan Allah SWT. Atas segala karunia yang diberikan oleh Allah SWT. Manusia dapat berkehendak bebas, tetapi kebebasan ini tidaklah berarti manusia terlepas dari qadha dan qadar yang merupakan hukum sebab akibat yang didasarkan pada pengetahauan dan kehendak Allah SWT. Kebebasan dalam melakukan aktivitas harus tetap memiliki batasan agar tidak menzalimi pihak lain. Hal inilah yang tidak terdapat dalam ekonomi konvensional, sehingga yang terjadi kebebasan yang dapat mengakibatkan pihak lain menderita.

4. Amanah (Pertanggungjawaban) 
Manusia adalah pengemban amanat Allah SWT. Manusia diberi kekuasaan untuk melaksanakan tugas kekhalifahan ini dan untuk mengambil keuntungan dan manfaat sebanyak-banyaknya atas ciptaan Allah SWT. Dalam hal konsumsi, manusia dapat berkehendak bebas tetapi ia haru mempertanggungjawabkan atas kebebasan tersebut, baik dalam keseimbangan alam, masyarakat, diri sendiri maupun di akhirat kelak. Pertanggungjawaban sebagai seorang Muslim bukan hanya kepada Allah SWT, melainkan kepada lingkungan. Jika ekonomi konvensional, baru mengenal istilah corporate social responsibility, ekonomi Islam telah mengenalnya sejak lama.

\section{Halal}

Dalam kerangka acuan Islam, barang-barang yang dapat dikonsumsi hanyalah barang-barang yang menunjukkan nilai-nilai kebaikan, kesucian, keindahan dan menimbulkan kemahlahatan untuk umat, baik secara material maupun spiritual. Sebaliknya benda-benda yang buruk, tidak suci, tidak bernilai, tidak dapat digunakan dan tidak dapat dianggap sebagai barang-barang konsumsi dalam Islam yang dapat menimbulkan kemudharatan apabila dikonsumsi akan dilarang.

\section{Sederhana}

Islam sangat melarang perbuatan yang melampaui batas (israf), termasuk pemborosan dan berlebih-lebihan (bermewah-mewah), yaitu membuang-buang harta dan menghambur-hamburkannya secara tidak rasional, tanpa faedah serta manfaat dan hanya memperturutkan nafsu. Allah SWT akan sangat mengecam setiap perbuatan yang melampaui batas. Allah SWT berfirman dalam Q.S. Al Maidah ayat 87: “Wahai orang-orang beriman! Janganlah kamu mengharamkan apa yang baik yang telah dihalalkan Allah kepadamu, dan janganlah kamu melampaui batas. Sesungguhnya Allah tidak menyukai orangorang yang melampaui batas". 
Perilaku konsumsi diatur dalam Islam sedemikian rupa, dari literaturliteratur yang ada bahwa pendapat-pendapat bersumber pada kalam Illahi. Dalam melakukan aktifitas konsumsi Islam memperhatikan nilai-nilai etika, secara garis besarnya berkonsumsi sesuai kebutuhan, menggunakan rasionalitas, tidak boros dan membatasi keinginan yang tidak berfaedah.

Peneliti mencermati konsumerisme dalam perspektif Islam dapat dimaknai sebagai perilaku konsumsi yang sangat bertolak belakang dengan prinsip perilaku konsumsi yang diajarkan dalam Islam. Konsumerisme adalah perilaku konsumsi konvensional yang memiliki ciri konsumen yang berkehendak bebas tanpa batas, berlebihan, tidak rasional, berorientasi pada kepuasan dan pengakuan diri. Dalam pandangan Islam, konsumerisme dilarang karena termasuk ke dalam perilaku berlebih-lebihan, hanya berorientasi pada kepuasan duniawi dan menumbuhkan sifat sombong. Islam mengajarkan perilaku konsumsi yang menganut paham keseimbangan dalam berbagai aspek, sesuai kebutuhan dan memiliki nilai manfaat sesuai dengan rasionalitas, yang berarti bahwa jika memahami betul konsep pola konsumsi yang diajarkan oleh Islam maka manusia dapat membatasi keinginanya sesuai dengan kebutuhan dan manfaat yang berujung pada terkikisnya perilaku boros, kikir dan sombong.

\section{SIMPULAN}

Konsumerisme merupakan perilaku konsumsi berlebihan dan irasional yang mendahulukan keinginan daripada kebutuhan dengan tidak memprioritaskan manfaat cenderung kepada sifat boros, kepuasan dan pengakuan diri. Menurut perspektif Islam, konsumerisme tindakan yang tidak dianjurkan karena termasuk ke dalam perilaku berlebih-lebihan, hanya berorientasi pada kepuasan duniawi dan menumbuhkan sifat sombong. Islam mengajarkan perilaku konsumsi yang menganut paham keseimbangan dalam berbagai aspek, sesuai kebutuhan dan memiliki nilai manfaat sesuai dengan rasionalitas, yang berarti bahwa jika memahami betul konsep pola konsumsi yang diajarkan oleh Islam maka manusia dapat membatasi keinginanya sesuai dengan kebutuhan dan manfaat yang berujung pada terkikisnya perilaku boros, kikir dan sombong. 


\section{DAFTAR PUSTAKA}

\section{Buku}

Amri Darwis. 2014. Metodologi Penelitian Pendidikan Islam. Cet.I Jakarta: Rajawali Press.

Ika Yunia Fauzia, Abdul Kadir Riyadi. 2014. Prinsip Dasar Ekonomi Islam Perspektif Maqasid al-Syariah. Cet.I. Jakarta: Kencana.

Juhaya S. Pradja. 2015. Ekonomi Syariah. Cetakan II. Bandung: Pustaka Setia.

M. Nur Rianto Al Arif. 2017. Pengantar Ekonomi Syariah Teori dan Praktik. Cet. 2. Bandung: Pustaka Setia.

Rozalinda. 2016. Prinsip Dasar Ekonomi Islam Perspektif Maqasid al-Syariah. Cet. 3. Jakarta: RajaGrafindoPersada.

Setiaji, B. 1995. Konsumerisme, Akademika No. 1. Tahun XIII. Surakarta: Muhammadiyah University Press.

Yadi Janwari. 2016. Pemikiran Ekonomi Islam Dari Masa Rasulullah Hingga Masa Kontemporer. Cet.I Bandung: Rosdakarya.

Yuniarti, V. S. 2015. Perilaku konsumen - teori dan praktik. Cet.I Bandung: Pustaka Setia

Wiratna Sujarweni. 2014. Metodologi Penelitian. Cet.I Yogyakarta: Pustaka Baru.

\section{Artikel}

Bagas Tripambudi, Endang Sri Indrawati, Hubungan Antara Kontrol Diri Dengan Perilaku Konsumtif Pembelian Gadget Pada Mahasiswa Teknik Industri Universitas Diponegoro, Jurnal Empati, Vol. 7 No. 2, 2018

Chandra Kurniawan, Analisis Faktor-Faktor Yang Mempengaruhi Perilaku Konsumtif Ekonomi Pada Mahasiswa, Jurnal Media Wahana Ekonomika, Vol. 13 No. 4, 2017

Rabia Jamil, Muh. Arsyad, dan Ambo Upe, Perilaku Konsumeris Pengunjung Mall Lippo Plaza Kota Kendari, Jurnal Neo Societal, Vol. 3 No. 2, 2018

Triyaningsih, Dampak Online Marketing Melalui Facebook Terhadap Perilaku Konsumtif Masyarakat, Vol. 11 No. 2, 2011 


\section{Literatur Online}

https://kbbi.web.id/ diakses tanggal 2 Maret 2020 Pukul 20.00 WIB. 
